\title{
A new cooling technique for stingless bees hive
}

\author{
Ahmad Syazwan Ramli $^{1}$, A. H. Luqman ${ }^{1}$, Firdaus Basrawi ${ }^{1,}{ }^{*}$, Ahmed N. Oumer ${ }^{1}$, Azizuddin \\ Abd Aziz ${ }^{1}$, and Zulkifli Mustafa ${ }^{2}$
}

${ }^{1}$ Meliponini Engineering Laboratory (MePEL), Energy Sustainability Focus Group (ESFG), Faculty of Mechanical Engineering, Universiti Malaysia Pahang (UMP), 26600 Pekan, Malaysia ${ }^{2}$ Department of Neurosciences, School of Medical Sciences, Health Campus, Universiti Sains Malaysia (USM), 16150 Kubang Kerian, Malaysia

\begin{abstract}
Stingless bees are a type of insect that are very sensitive to the changes of their surroundings, especially to severe heat wave. A report stated that at temperature as high as $38^{\circ} \mathrm{C}$ can cause death of bees especially to the pupae. Therefore, the objective of this research is to evaluate a new method in regulating the temperature in the hive. Greenroof, a type of roof which contains green vegetation and soil, was used as the cooling method in this study. Two units of MUSTAFA-hives were exposed under sunlight, one is without temperature control and another one was fitted greenroof. The temperatures inside each hive was measured at two points and was compared with the hive without temperature control. It was found that, for the hive integrated with greenroof, the average hive temperature was about $3{ }^{\circ} \mathrm{C}$ and $6{ }^{\circ} \mathrm{C}$ lower in the honey cassette and brood-cells compartment, respectively. Therefore, it can be concluded that the implementation of greenroof could solve the problem of stingless bee hive overheating, and the greenroof has an impressive cooling performance besides being an economic and simple solution.
\end{abstract}

\section{Introduction}

Stingless bees are fascinating creatures. They predate the stinging honey bee, roaming the tropical earth for over 65 million years. They are diverse and although they share some similarities with Apis they are biologically distinct. Stingless bees species are common to tropical and subtropical areas such as the South-east asia region. Diversity of stingless bees makes classifying them a difficult task, especially in Indo-Malayan region [1]. Like honeybees, stingless bees produce honey in nest containing sterile workers and a queen. However, stingless bees produce less honey, and do not use water to cool their nest. [2]. Their hives usually consist of sections of broodcell area, as well as honey pot area. In tropical region, their nests are made in trees.

Hive temperature of $38^{\circ} \mathrm{C}$ and above can cause death in pupae development [3]. This is detrimental towards the growth of colony. In natural hives, thermostatic effect helps thermoregulation, where the wood insulation along with shades, are able to keep the temperature of the hive relatively constant [4].

\footnotetext{
*Corresponding author: mfirdausb@ump.edu.my
} 
Typically, trees are cut down to obtain log containing the stingless bees nests. The log is then attached with a topping compartment to facilitate the honey production. However, such practice can be damaging towards the natural ecosystem especially for tropical jungles and are not sustainable in long term. As stingless bees are natural pollinator for tropical forests, the human disturbance to stingless bees community could potentially disrupt and alter the forest composition [5]. Hence, once a colony is obtained from a log, it can be transferred into artificial hives such as MUSTAFA-hives. Then, it can be split into two colonies. Once the colonies settled and become stable it can be divided again and again. The honey can be easily extracted as MUSTAFA-hives has separate honey cassette compartment. Thus, this minimizes the disturbance and intrusion into the colony.

Colonies in hives are often placed under trees or other suitable shaded areas. This is to prevent the hives from overheating especially in tropical hot and humid climate. Placing the hives under direct sunlight can cause temperature to build up and can be dangerous to the colony as pupae in broodcell could die when subjected to extreme heat. Hence, suitable cooling method for hives may be developed to prevent overheating of hives when subjected to outdoor conditions.

A possible cooling method is by using greenroof, a natural cooling technique that have been used for centuries [6]. Although the technique is centuries old, due to scarcity of planted surface in urban areas, greenroof become stabilising and efficient choice [7]. Essentially, a green roof is a type of roof made up of vegetation and soil as its outermost surface [8]. As vegetation have potential to provide cooling benefits [9], buildings using greenroofs could reduce their inside temperatures as much as $3.4^{\circ} \mathrm{C}$ [10]. Therefore, greenroof have potential to be adapted to cool stingless bees hive.

From literature reviewed, there is no study reported on the greenroof based cooling method for stingless bees hive. Thus, the main objectives of this study are:

- to investigate the temperature profile of a hive exposed to outdoor conditions, and

- to evaluate the temperature regulation in the hive using greenroof as a cooling method.

The study was carried out by exposing two MUSTAFA-hives to outdoor condition. One of the hive was fitted with greenroof and another hive was left as control. The temperature profile of the hives was recorded.

\section{Materials and method}

An experiment was carried out at Universiti Malaysia Pahang, Pekan campus (coordinates: $3.5437^{\circ} \mathrm{N}, 103.4288^{\circ} \mathrm{E}$, GMT +8 ). Two identical MUSTAFA hives were exposed to outdoor conditions; without any shade. One of the hive was fitted with greenroof as the cooling technique. Temperature readings were taken inside the broodcell compartment and honey cassette for each hives every five minutes during the day using thermocouples. The measurement was recorded by a data logger (Lutron BTM-4208SD), which was then transferred into computer for further analysis. Figure 1 shows the typical construction of a MUSTAFA-hive, where the hive is divided into three main components, which are the broodcell compartment, the honey cassette and the roof. In the brood cell compartment, a 25 $\mathrm{mm}$ diameter hole acts as the only entry and exit for stingless bees. The broodcell compartment is connected to the honey cassette with a $35 \mathrm{~mm}$ diameter hole. This provided access for the bees to store honey. The hives used in the experiment are all empty hives without colony, to ensure no thermal exchange occur with a living colony as well as to no disrupt them. 


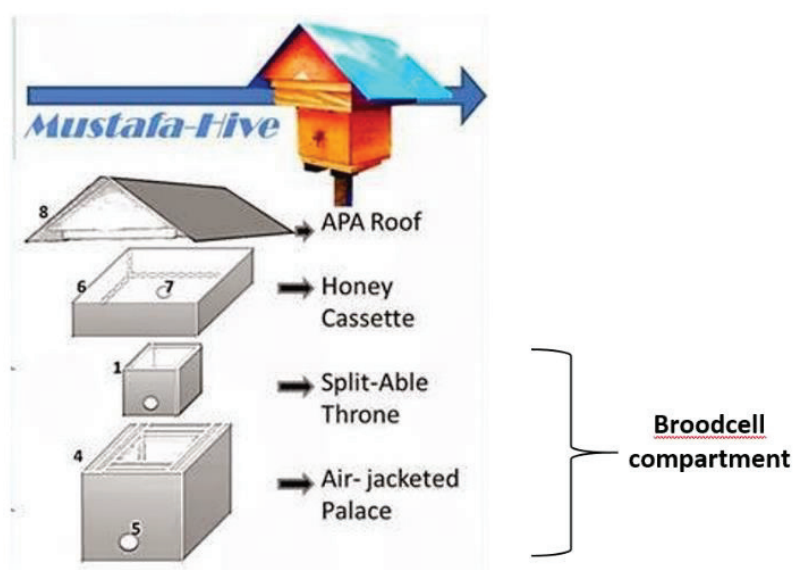

Figure 1: Typical construction of a Meliponiculture Using a Split-able Throne within Air-jacketed palace For Amplification-hive (MUSTAFA-hive)

Error! Reference source not found. shows the overall greenroof construction used in the experiment. The greenroof used was made up of four main components, which are the vegetation or the plant, some soil and sand mixture in semi dry condition, a polyethylene layer as root barrier, and wooden planks as roofing material and container.

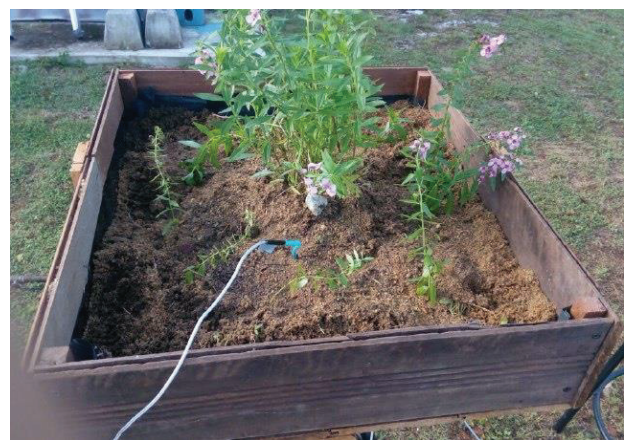

Figure 2: Greenroof used in experiment, made up of vegetation, soil and sand mixture, polyethylene layer, and wooden planks

Figure 3 shows the overall experimental setup. Two hives were exposed to outdoor conditions without any shades. The hive on the right was fitted with a greenroof, and the hive on the left was not fitted with any cooling technique and acted as a control hive. 


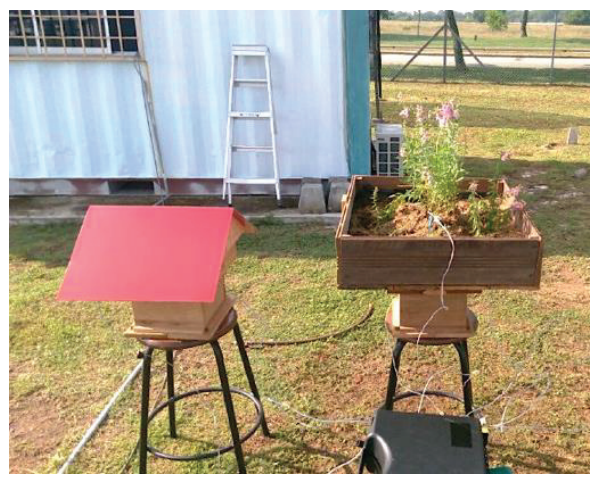

Figure 3: Overall setup, with thermocouples measuring temperatures inside honey cassette and brood cell compartment of each hives, connected to a temperature data logger

\section{Results and discussion}

Table 1 shows the maximum, minimum, and average temperature inside the honey cassette and broodcell compartment of each hives. The control hive showed that, without cooling technique, the maximum temperature in the broodcell compartment could rise as high as 39.8 ${ }^{\circ} \mathrm{C}$ while in the honey cassette the maximum temperature was at $34.7^{\circ} \mathrm{C}$. This showed the need for cooling especially in the broodcell compartment.

Table 1: Minimum, maximum, and average temperatures in the honey cassette and broodcell compartment of the hives

\begin{tabular}{|l|l|l|l|l|}
\hline & \multicolumn{2}{|l|}{ Honey cassette } & \multicolumn{2}{l|}{ Broodcell } \\
\hline Temperature $\left({ }^{\circ} \mathrm{C}\right)$ & Control & Greenroof & Control & Greenroof \\
\hline Minimum & 30.1 & 28.3 & 30.6 & 27.9 \\
\hline Maximum & 34.7 & 30.8 & 39.8 & 31.6 \\
\hline Average & 33.0 & 29.7 & 36.7 & 30.2 \\
\hline
\end{tabular}

Greenroof showed significant cooling effect, where the average temperatures recorded are, $29.7{ }^{\circ} \mathrm{C}$ and $30.2{ }^{\circ} \mathrm{C}$ in the honey cassette and broodcell compartment respectively. This translated to an average of $3.3^{\circ} \mathrm{C}$ and $6.5^{\circ} \mathrm{C}$ lower than the control hive. Apart from that, greenroof recorded $3.9{ }^{\circ} \mathrm{C}$ and $8.2^{\circ} \mathrm{C}$ lower maximum temperatures for the honey cassette and broodcell compartment, respectively.

Figure 4 shows the temperature profile inside the honey cassette, represented by solid lines and broodcell compartment, represented by the pecked lines. The circle, and triangle represented the control hive, and hive with greenroof, respectively. 


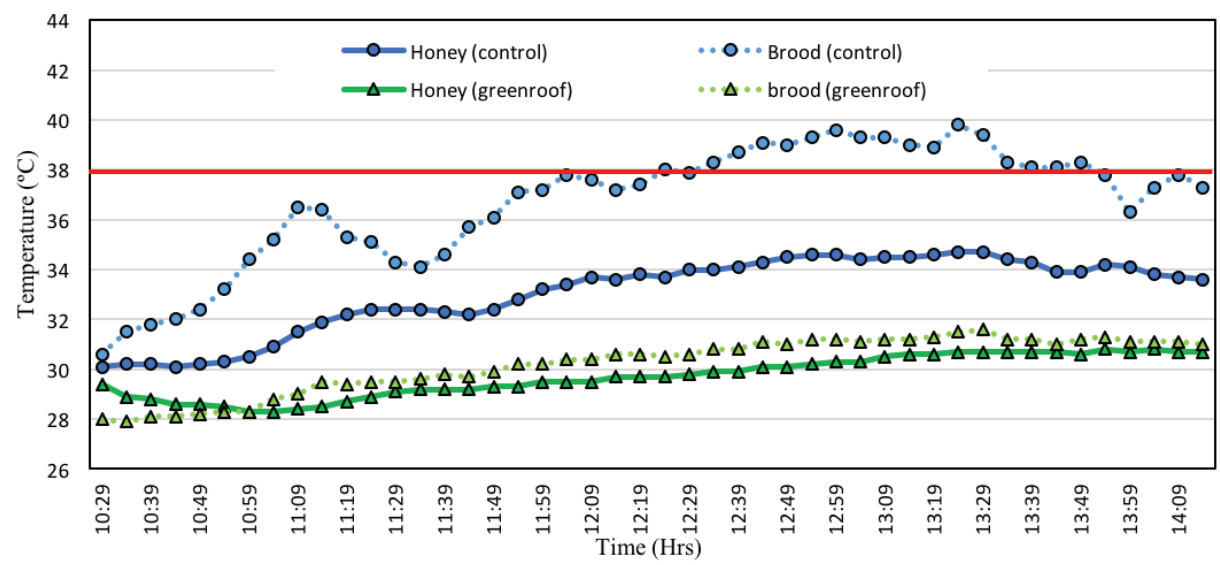

Figure 4: Temperatures inside broodcell compartment and honey compartment during the day for the control hive and hive fitted with greenroof

In the control hive, the broodcell compartment experienced a prolonged temperature rise above $38{ }^{\circ} \mathrm{C}$, more than an hour, recorded around noon. For a colony, such extreme temperature are lethal to pupae in the broodcell compartment [3]. This can cause the colony to collapse and die out. The broodcell compartment also recorded significantly higher temperature compared to the honey cassette. This could partly be due to the roof covering most of the honey cassette from sun radiation while less covering of the broodcell compartment. As the hive was a closed system, the hot air may be trapped inside the broodcell compartment with only one exit, disrupting natural hot air circulation upwards.

The hive with greenroof recorded stable temperatures, with the broodcell compartment recorded just slightly higher temperatures than the honey cassette. When compared to the control hive, the temperatures were consistenly lower than the control hive, showing significant cooling effect around noon. The temperatures recorded were close to optimum temperature for stingless bees species such as Trigona denoiti, which the broodcell area optimum temperatures are between $31{ }^{\circ} \mathrm{C}$ and $32{ }^{\circ} \mathrm{C}$ [11]. These results were impressive considering the greenroof is relatively easy and simple to set up.

\section{Conclusion}

Two hives were exposed to outdoor conditions, with one hive without cooling technique and another hive was fitted with greenroof, acted as a control hive. The broodcell compartment in both hives recorded higher temperatures compared to the honey cassette. This could be explained by low air convection inside the hive, which caused most of heat transfer to occur inside the broodcell compartment. In the control hive, the broodcell compartment experienced prolonged temperature rise above $38{ }^{\circ} \mathrm{C}$ of more around noon. This could lead to death of pupae in broodcell. On the other hand, it was found that the hive fitted with greenroof has an impressive cooling performance. The temperatures inside the hive fitted with greenroof were significantly lower than the control hive when exposed to outdoor conditions without any shades. The average temperature reduction from the experiment were $3.3{ }^{\circ} \mathrm{C}$ and $6.5{ }^{\circ} \mathrm{C}$ in the honey cassette and broodcell compartment respectively. The temperatures recorded were relatively stable and were very close to optimum temperature of broodcell area in natural hives. Thus, it can be concluded that the greenroof is a feasible and economical solution towards cooling stingless bees hives. 
The authors would like to thank Universiti Malaysia Pahang for providing Research Grant under RDU140119.

\section{References}

[1] F. Schwarz, "The Indo-Malayan Species of Trigona," Am. Museum Nat. Hist., vol. 76, no. 3, pp. 83-141, (1939).

[2] D. W. Roubik, "Stingless bee nesting biology," Apidologie, vol. 37, no. November, pp. 124-143, (2006).

[3] A. Vollet-Neto, C. Menezes, and V. L. Imperatriz-Fonseca, "Behavioural and developmental responses of a stingless bee (Scaptotrigona depilis) to nest overheating," Apidologie, vol. 46, no. 4, pp. 455-464, (2015).

[4] I. H. Sung, S. Yamane, and S. Hozumi, "Thermal characteristics of nests of the Taiwanese stingless bee Trigona ventralis hoozana (Hymenoptera: Apidae)," Zool. Stud., vol. 47, no. 4, pp. 417-428, (2008).

[5] H. Samejima, M. Marzuki, T. Nagamitsu, and T. Nakasizuka, "The effects of human disturbance on a stingless bee community in a tropical rainforest," Biol. Conserv., vol. 120, no. 4, pp. 577-587, (2004).

[6] E. P. Del Barrio, "Analysis of the green roofs cooling potential in buildings," Energy Build., vol. 27, no. 2, pp. 179-193, (1998).

[7] A. Niachou, K. Papakonstantinou, M. Santamouris, A. Tsangrassoulis, and G. Mihalakakou, "Analysis of the green roof thermal properties and investigation of its energy performance," Energy Build., vol. 33, no. 7, pp. 719-729, (2001).

[8] D. J. Sailor, "A green roof model for building energy simulation programs," Energy Build., vol. 40, no. 8, pp. 1466-1478, (2008).

[9] S. A. Shiflett, L. L. Liang, S. M. Crum, G. L. Feyisa, J. Wang, and G. D. Jenerette, "Variation in the urban vegetation, surface temperature, air temperature nexus," Sci. Total Environ., vol. 579, pp. 495-505, (2017).

[10] V. W. Y. Tam, J. Wang, and K. N. Le, "Thermal insulation and cost effectiveness of green-roof systems: An empirical study in Hong Kong," Build. Environ., vol. 110, pp. 46-54, (2016).

[11] D. J. C. Fletcher and R. M. Crewe, "Nest structure and thermoregulation in the stingless bee, Trigona denoiti, Hymenoptera: Apidae," J. Entomol. Soc. South Africa, vol. 44, no. 2, pp. 183-196, (1981). 